\title{
Drainage changes in the Nero Lake Basin, central European Russia
}

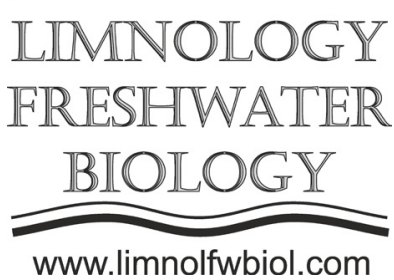

\author{
Ukraintsev V.Yu. ${ }^{1,2 *}$, Konstantinov E.A. ${ }^{1}$, Zakharov A.L. ${ }^{1}$ \\ ${ }^{1}$ Institute of Geography, Russian Academy of Sciences, Staromonetny st., 29, Moscow, 119017, Russia \\ ${ }^{2}$ Water Problems Institute, Russian Academy of Sciences, Gubkina st., 3, Moscow, 119333, Russia
}

\begin{abstract}
Large paleochannels are widespread in the surroundings of Lake Nero, they are larger than modern ones. Their presence indicates an increased river run-off in the past and a likely impact on changes in lake level. The study of paleochannels was carried out using hydro-morphological analysis and drilling cores. The results showed that their sizes are to 1.5-3 times larger than modern analogues. At the time of their formation, river discharges exceeded recent ones, the lake was in regression. The paleochannels north of the Rostov belong to the Ustye paleoriver, which had previously flowed into the Nero with a level below $91 \mathrm{~m}$ a.s.l. Further study of the river paleochannels will help to better understand the reasons for the change of Nero Lake level.
\end{abstract}

Keywords: Nero Lake, large paleochannels, Late Pleistocene - Holocene.

\section{Introduction}

Lake Nero, located on the Rostov lowland, is one of the main paleogeographic objects of study in the upper Volga basin. Early researchers studied the development of the lake in the Pleistocene and Holocene, its terraces and hollow, as well as the adjacent Borisoglebsk Upland, which is an important object for reconstructions of the glacial and interglacial eras of the central European Russia. Paleogeographic models of the lake and the environment were built on the basis of classical methods (stratigraphic, palynological, diatom, etc.). Recently, the attention of researchers has been riveted to the dynamics of the lake level after the LGM - an era that seriously affected the environmental changes of the East European Plain. However, poorly developed is the question of the causes and mechanisms of lake level change in LGM, which could explain it's dynamic. The solution to this problem can be facilitated by the study of paleochannels in the lower reaches of the Ishnya River flowing into the lake, discovered by N. V. Chizhikov (1956). The reconstruction of the water balance elements of the lake tributaries will help to come closer to understanding the causes of the lake dynamics after LGM.

\section{Materials and methods}

The research methodology included the recognition of large paleochannels in the vicinity of Lake Nero using satellite images from Yandex, ESRI and
Google, as well as ALOS 3D digital elevation model. Measurements, mapping and analytical calculations were carried out in SAS Planet v.20, Arcmap 10.3, Microsoft Office Excel. The calculation of discharges and other indicators was carried out according to the method described in the work of Sidorchuk and Panin (2017). Since paleochannels are well expanded by paleostreams, the width was measured in the narrowest sections. In addition, in February 2020, an expedition to the lake was conducted with drilling of the paleochannels to the north of the Varnitsky monastery in Rostov using the Eijkelkamp hand drill (3 boreholes with depth 5-8 m). A samplers has length 40-100 $\mathrm{cm}$, and diameter $3-5 \mathrm{~cm}$. Drilling was accompanied by geodetic measurements using DGPS. The drill log carried out in the CorelDraw X7.

\section{Results}

In satellite images, large paleochannels are clearly visible to the north and northeast of the town of Rostov. Now they are occupied by the rivers Ishnya and Moshna. Even larger point bar series and paleomeanders are located north of the Kotorosl' River from its heads to the confluence with the Lahost' River. Also, the Mogza and Sara rivers have inherited large paleochannels and oxbow lakes. Since there were no restrictions in the choice, for the measurements we selected the most pronounced 10 sections of Ishnya paleochannels for measuring the width and 15 for measuring the wavelength (for series of meanders). The 
average width turned out to be $89 \mathrm{~m}$, the mean meander wavelength is $557 \mathrm{~m}$. The calculated mean maximum discharges are $20.7 \mathrm{~m}^{3}$ per second. Meanders north of the Kotorosl' River has meander wavelength about $1.7 \mathrm{~km}$, meanders of the Mogza River - $573 \mathrm{~m}$ (more than 3 times larger than the modern ones), meanders of the Sara river - $313 \mathrm{~m}$ (2 times larger than the recent ones). The boreholes subsurface structure is as follows (from top to bottom): sludge - sapropel - peat to a depth of 2-3 $\mathrm{m}$, then medium sand with plant residues and wood pieces, passing from 5-6 $\mathrm{m}$ into the coarse sand with pebbles or round loam pieces with pebble size.

\section{Discussion}

The widths of the paleochannels and their wavelength are perfectly correlated, since the width reconstructed from the meander wavelength turned out to be $92 \mathrm{~m}$. This indicates the reliability of the measurements made. The width and meander wavelengths exceed the modern channels of the Ustye River (width 30-40 m, the average wavelength 318 $\mathrm{m}$ ), flowing nearby, from which, most likely, these paleochannels were cut-off (this was suggested by N.V. Chizhikov (1956)). The paleoriver flowed into the lake at an altitude below $91 \mathrm{~m}$ a. s. 1. (the top of coarse sand, that is channel alluvium), as evidenced by the recent and ancient river gradient. The paleomeanders north of Kotorosl' River appear to reflect another age of meanders, since they are significantly larger. The reconstructed discharges turned out to be rather low. Modern mean annual discharge in Ustye River before the confluence of Mogza is $0.58 \mathrm{~m}^{3}$ per second, the mean maximum discharge is $14 \mathrm{~m}^{3}$ per second (USSR Surface ..., 1984). Calculated by the channel depth and width, and the midstream speed of the Ustye River (shown on the map of the USSR General Staff on a scale of 1: 100 000 before the confluence with the Vyoksa River), the modern discharge is $20 \mathrm{~m}^{3}$ per second. However, this is a normal situation for rivers with a basin of less than $5,000 \mathrm{~km}^{2}$, since in such basins the difference of the mean annual and maximum water discharge can be several tens or even hundreds of times (Chalov et al., 2004), which does not allow reconstructing the river run-off and paleoclimatic precipitation indicators. But the fact that the paleoriver flowed into Lake Nero, as well as minimal discharges that we calculated, allow us to confidently say that the water income to the lake was much higher than recent. In addition, the paleostream could fall apart as Paleo-Ustye flowed through the inner delta. However, most likely, the era of high water corresponded to the regression of the lake (below $91 \mathrm{~m}$ a. s. 1. compared to the current lake level, exceeding $93 \mathrm{~m}$ a. s. 1.), whose age is estimated at $14-7.5 \mathrm{ka}$ (Wohlfarth, 2006). The formation of the large paleochannels at the East European Plain is attributed to the Late Glacial and first half of Holocene, probably at the same time paleochannels near Nero formed. In the future, when we get radiocarbon age for the samples, it will be possible to confidently attribute this era to a specific time slice.

\section{Conclusions}

The paleochannels dimensions near Nero Lake are 1.5-3 times larger than recent analogues. At the time of their formation, river discharges exceeded recent ones, the lake was in regression. The paleochannels north of the Rostov belong to the Ustye paleoriver, which had previously flowed into the Nero with a level below 91 $\mathrm{m}$. Further study of the rivers paleochannels will help to better understand the reasons for the change in its level.

\section{Acknowledgements}

The studies are carried out with the financial support of the Russian Science Foundation, project 1917-00215. We thank Sychyov N.V., Baranov D.V. and Berdnikova A.A. for the drilling help.

\section{Reference}

Chalov R.S., Zavadsky A.S., Panin A.V. 2004. River meanders. Moscow: University Press. (in Russian)

Chizhikov N.V. 1956. Geomorphology and soils of the Nero Lake Basin and the Ustye-Kotorosl' River. - In: Proceedings of the sapropelic deposits laboratory. No. VI (Trudy laboratorii sapropelevykh otlozheniy. № VI). Moscow: Publishing House of the Academy of Sciences of the USSR, pp. 130-144. (in Russian)

Sidorchuk A.Y., Panin A.V. 2017. Geomorphological approach to the river runoff evaluation in the geological past (paper 2. Estimation of river Palaeo-discharges based on channel hydraulics). Geomorphology RAS (Geomorfologiya) 2: 3-13. (in Russian)

USSR Surface Water Resources: Hydrological knowledge. 1973. Upper Volga region, book 2. In: Yablokova E.Yu. (Ed.). Moscow: Gidrometeoizdat, (in Russian)

Wohlfarth B. et al. 2006. Late Glacial and Holocene Palaeoenvironmental Changes in the Rostov-Yaroslavl' Area. Journal of Paleolimnology 35(3): 543-569. 